\title{
PERBAIKAN KADAR HIDRASI KULIT DENGAN INTERVENSI MINYAK KLENTIQ PADA LANSIA STW CIBUBUR PERIODE SEPTEMBER 2019
}

\author{
Sukmawati Tansil Tan¹, Yohanes Firmansyah², Yana Sylvana ${ }^{2}$, Noer Saelan Tadjudin ${ }^{3}$ \\ ${ }^{1}$ Bagian Ilmu Penyakit Kulit dan Kelamin, Universitas Tarumanagara \\ Email:sukmawati@fk.untar.ac.id \\ ${ }^{2}$ Asisten Peneltian Ilmu Penyakit Kulit dan Kelamin, Universitas Tarumanagara \\ Email: yohanesfirmansyah28@gmail.com dan sylvanayana@gmail.com \\ ${ }^{3}$ Bagian Ilmu Penyakit Jiwa, Universitas Tarumanagara \\ Email:saelampml@gmail.com
}

Masuk: 26-11-2019, revisi: 11-05-2020, diterima untuk diterbitkan: 12-05-2020

\begin{abstract}
ABSTRAK
Population Reference Bureau (PRB) memperkirakan bahwa Indonesia akan mengalami lonjakan populasi menjadi 365,3 juta jiwa pada tahun 2030 yang selanjutnya akan berdampak terhadap lonjakan populasi lanjut usia serta peningkatan permasalahan kesehatan yang terjadi pada lansia. Salah satu permasalahan kesehatan lansia yang sering terjadi pada kulit adalah masalah hidrasi kulit. Tujuan penelitian ini adalah untuk mencari peningkatan kadar hidrasi kulit lansia setelah penelitian intervensi berupa minyak Klentiq. Penelitian ini merupakan penelitian quasi eksperimental, dengan metode pengambilan sampel berupa total sampling. Penelitian dilakukan di Panti STW RIA Pembangunan Cibubur pada periode September 2019. Variabel bebas dalam penelitian ini adalah penggunaan Minyak Klentiq selama 21 hari dan variabel tergantung dalam penelitian ini adalah perubahan kadar hidrasi kulit lengan kanan bawah. Hubungan antar variabel di uji dengan Repeated Measurement. Terdapat 51 responden yang memenuhi kriteria inklusi dan mengikuti penelitian hingga akhir. Uji statistik Repeated Measurement didapatkan hasil kenaikan hidrasi kulit pada lengan kanan bawah yang bermakna (p-value < 0,001) antar pengukuran setelah pemberian intervensi berupa Minyak Klentiq. Peningkatan kadar hidrasi lengan kanan bawah paling tinggi adalah antara pengukuran minggu ke nol dengan minggu ke tiga yaitu sebesar 2,637 $(0,300) \%$. Sebagai kesimpulan, Minyak Klentiq terbukti meningkatkan kadar hidrasi kulit pada lansia ( $\mathrm{p}$-value $<0,001$ ) dengan pemakaian selama 21 hari.
\end{abstract}

Kata Kunci: Hidrasi kulit; Minyak Klentiq; Lansia

\begin{abstract}
The Population Reference Bureau (PRB) estimates that Indonesia will experience a population surge to 365.3 million by 2030, which will further affect the surge in the elderly population and increase health problems occurring in the elderly. One of the elderly health problems that often occur on the skin is skin hydration. The purpose of this study is to look for an increase in the hydration level of elderly skin after intervention studies in the form of Klentiq oil. This research is a quasi-experimental study, with a total sampling method in the form of sampling. The study was conducted at the STW RIA Pembangunan Cibubur in September 2019, using the statistical test Repeated Measurement results a significant increase in hydration (p-value <0.001) between measurements after giving intervention in the form of Klentiq Oil. The highest increase of hydration level is between the measurement of week zero and week three which is 2,637 (0,300)\%. It is advisable to continuously (routinely) use Klentiq oil for at least 3 weeks in order to improve the hydration level and skin hydration status, and doesn't have to worry about being used in the long term usage.
\end{abstract}

Keywords: Skin hydration; Klentiq Oil; Elderly 


\section{PENDAHULUAN}

\section{Latar Belakang}

Proses penuaan merupakan sebuah proses alamiah yang terjadi pada semua manusia tanpa terkecuali. Proses penuaan sendiri akan menyebabkan perubahan secara anatomi maupun fisiologi yang tentunya berdampak pada aspek kehidupan manusia baik sosial, ekonomi, maupun kesehatan. Seiring dengan majunya ilmu pengetahuan serta teknologi, diketahui bahwa proses penuaan dapat diperlambat dengan berbagai cara yang meliputi peningkatan promosi kesehatan, perbaikan gizi, perbaikan gaya serta pola hidup, dan peningkatan ilmu pengetahuan dalam bidang kedokteran.(Shai, Maibach, \& Baran, 2009). Seiring dengan meningkatnya angka harapan hidup, jumlah populasi lanjut usia di dunia mengalami peningkatan yang signifikan. Sensus World Health Organization (WHO) memperkirakan kenaikan populasi lanjut usia di dunia sebesar 10\% sampai $22 \%$ atau dari 800 juta jiwa menjadi 2 milyar jiwa. Populasi lanjut usia di Benua Asia dan Asia Tenggara berturut-turut berjumlah 7\% dan 6\% dari seluruh total demografi. (Population Reference Bureau, 2016). Menurut sensus World Bank dikemukakan bahwa jumlah populasi lanjut usia di Indonesia berjumlah 5\% dari total populasi Indonesia yang berjumlah 252.812.245 jiwa.(The World Bank, 2012). Population Reference Bureau (PRB) memperkirakan bahwa Indonesia akan mengalami lonjakan populasi menjadi 365,3 juta jiwa pada tahun 2030 yang selanjutnya akan berdampak terhadap lonjakan populasi lanjut usia serta peningkatan permasalahan kesehatan yang terjadi pada lansia. (Population Reference Bureau, 2016). Salah satu permasalahan kesehatan lansia yang sering terjadi pada kulit adalah masalah hidrasi kulit yang selanjutnya dapat membuat gatal pada penderita lansia. (Hurlow \& Bliss, 2011; Leslie, 2016; Seyfarth, Schliemann, Antonov, \& Elsner, 2011; White-Chu \& Reddy, 2011)

Kulit merupakan organ terbesar manusia yang memiliki berat sekitar $16 \%$ dari total berat ubuh, Kulit memiliki berbagai fungsi seperti termoregulasi, fungsi barrier (proteksi), fungsi metabolisme serta regulasi, dan fungsi sensasi. Seiring dengan bertambahnya usia maka akan terjadi penurunan dari fungsi barrier (proteksi) baik dari barrier mekanik, barrier imunologi, dan barrier biokimia.(Fitzpatrick et al., 2008). Komponen barrier mekanik yang menjaga hidrasi kulit adalah statum korneum. Hidrasi serta kelembaban kulit di stratum korneum diatur secara endogen oleh natural moisturizing factor (NMF), interaksi lipid kulit, serta water channel proteins, terutama komponen aquaporin-3 (AQP-3). Aquaporin-3 (AQP-3) bertugas untuk melakukan transpor air serta gliseron yang berfungsi sebagai humektan alami. (Robinson, Visscher, Laruffa, \& Wickett, 2010). Seiring dengan bertambahnya usia maka ekspresi dari AQP-3 dan jumlah lipid pada stratum korneum akan mengalami penurunan sehingga akan menyebabkan penurunan hidrasi kulit. Selain usia, status hidrasi kulit sendiri dapat ditentukan pula oleh penggunaan sabun, frekuensi mandi, penyakit sistemik, trauma mekanik, penggunaan pelembab secara rutin dan banyak faktor lainnya. (Cao et al., 2008)

Pelembab kulit yang sedang berkembang saat ini adalah pelembab yang berasal dari minyak zaitun (virgin olive oil) dan minyak kelapa (virgin coconut oil). Salah satu alasan pengunaan minyak zaitun dan minyak kelapa adalah tingginya kandungan antioksidan pada minyak tersebut. Gabungan dari kedua minyak tersebut secara sinergis meningkatkan status hidrasi kulit pada lansia. Minyak kelapa berguna dalam memperbaiki komponen lipid yang berada pada lapisan stratum korneum, serta minyak zaitun yang bertugas sebagai barrier mekanik yang mencegah evaporasi air dari kulit. (Kappally, Shirwaikar, \& Shirwaikar, 2015)

Minyak Klentiq sendiri merupakan sebuah minyak khas Indonesia yang sudah dikenal secara turun temurun oleh masyarakat khususnya masyarakat suku Jawa, serta sebagai pengobatan tradisional pada berbagai kelainan kulit. Komposisi minyak Klentiq sendiri didominasi oleh 
gabungan minyak kelapa dan minyak zaitun, Indonesia sendiri sampai saat ini belum ada penelitian yang menganalisis hubungan penggunaan pelembab yang memiliki komposisi dari minyak zaitun dan minyak kelapa terhadap hidrasi kulit kelompok lanjut usia. Penatalaksaan kulit kering pada kelompok lanjut usia pun saat ini belum mendapatkan perhatian khusus di Indonesia. Penelitian ini dilakukan dengan tujuan untuk meningkatkan kesejahteraan lansia terutama dalam bidang kulit dengan produk yang mudah serta terjangkau.

\section{Rumusan Masalah}

Prevalensi kulit kering pada kelompok lansia sangat tinggi. Penelitian ini dilakukan untuk melihat pengaruh intervensi berupa minyak Klentiq (gabungan antara minyak zaitun dan minyak kelapa) terhadap kulit kering, serta mencari tahu peningkatan hidrasi kulit setelah intervensi minyak Klentiq selama 21 hari.

\section{METODE PENELITIAN}

Penelitian ini merupakan penelitian uji klinik dengan desain quasi eksperimental yang dilaksanakan di Panti Jompo STW Karya Bhakti Ria Pembangunan Cibubur pada periode September 2019. Sampel penelitian ini adalah seluruh kelompok lansia yang berada di tempat pengambilan sampel Panti Jompo STW Karya Bhakti Ria Pembangunan Cibubur pada periode September 2019 dan memenuhi kriteria inklusi. Besar sampel minimum pada penelitian ini yaitu sebesar 50 responden dengan metode pengambilan sampel berupa total sampling. Kriteria inklusi dalam penelitian ini adalah responden dengan usia $\geq 60$ tahun, bersedia menghentikan penggunaan obat pelembab lain yang telah digunakan minimal 3 hari. Kriteria eksklusi dalam penelitian ini adalah responden yang menolak ikut serta dalam penelitian, responden dengan gangguan kulit, yang berhubungan dengan penyakit infeksi, iritasi, dan curiga responden dengan riwayat alergi pada komposisi obat, atau responden dengan gangguan jiwa mayor dan kondisi psikotik berat. Variabel bebas dalam penelitian ini adalah penggunaan minyak Klentiq yang diaplikasikan pada lengan kanan bawah dua kali sehari yaitu setelah mandi pagi dan mandi sore, serta variabel tergantung dalam penelitian ini adalah hidrasi kulit lengan kanan bawah pada minggu ke $0,1,2$, dan 3, yang diukur pada pertengahan lengan bawah bagian ekstensor menggunakan instrument Skin Analyzer Runve HL-611. Analisis statistik menggunakan uji statistik Repeated Measurement untuk mengukur kemaknaan antar pengukuran secara simultan. Penelitian ini telah mendapatkan izin kaji etik dari Universitas Tarumanagara Human Research Ethic Community (UTHREC).

\section{HASIL DAN PEMBAHASAN}

Perubahan kadar hidrasi kulit lengan kanan bawah dari sebelum pemakaian Minyak Klentiq dan sesudah pemakaian Minyak Klentiq pada 51 responden berturut-turut pada minggu ke nol hingga minggu ketiga adalah sebesar 35,20 $\pm 2,96 \%, 36,32 \pm 2,60 \%, 37,04 \pm 2,10 \%$, dan 37,84 $\pm 2,20$. Analisa uji statistik menggunakan uji Repeated Measurement didapatkan hasil kenaikan hidrasi yang bermakna ( $\mathrm{p}$-value $<0,001$ ) antar pengukuran akibat pemberian intervensi berupa Minyak Klentiq. Peningkatan kadar hidrasi paling tinggi adalah antara pengukuran minggu ke nol dengan minggu ke tiga yaitu sebesar 2,637 (0,300)\%. 
Tabel 1. Perbandingan Kadar Hidrasi Kulit Lengan Kanan dengan Intervensi Minyak Klentiq pada Minggu ke-0 hingga Minggu ke -3

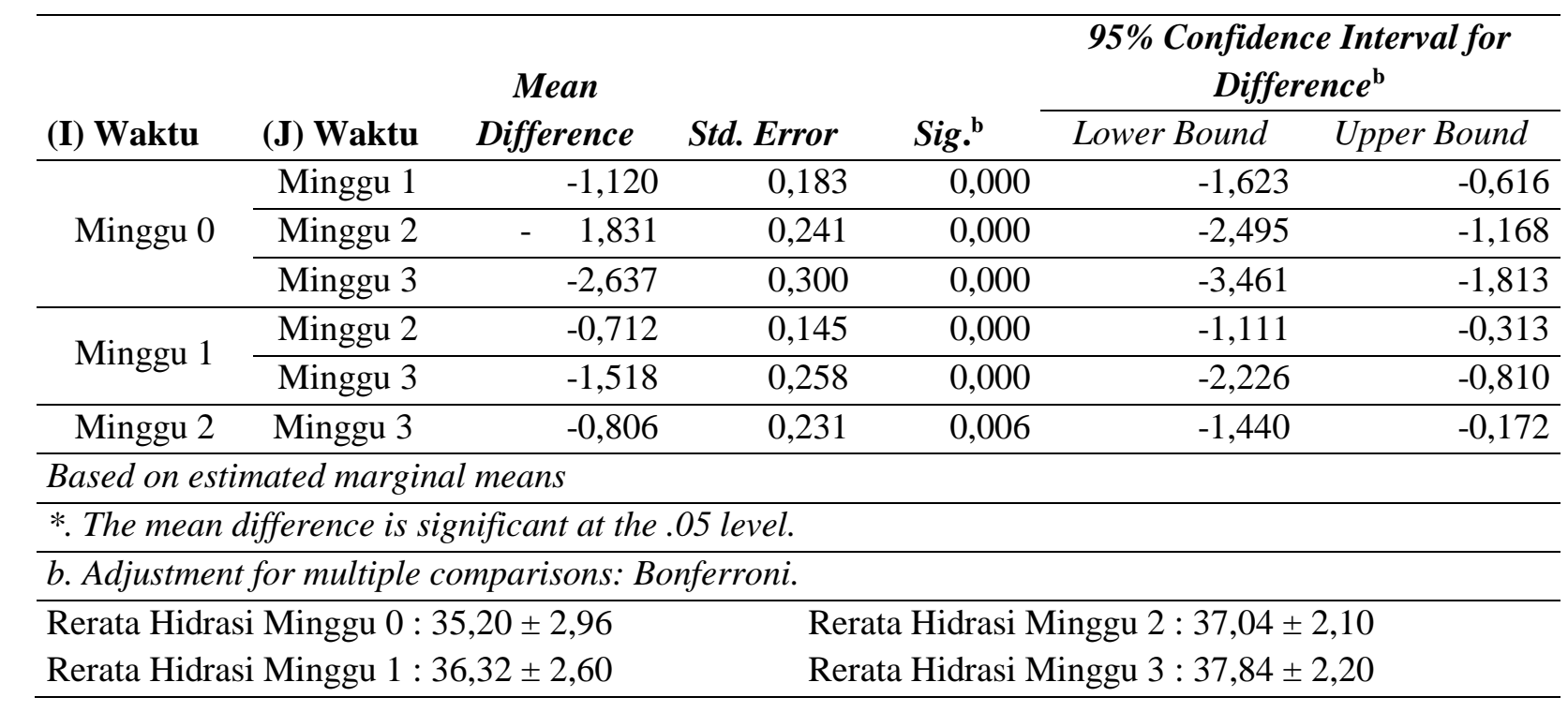

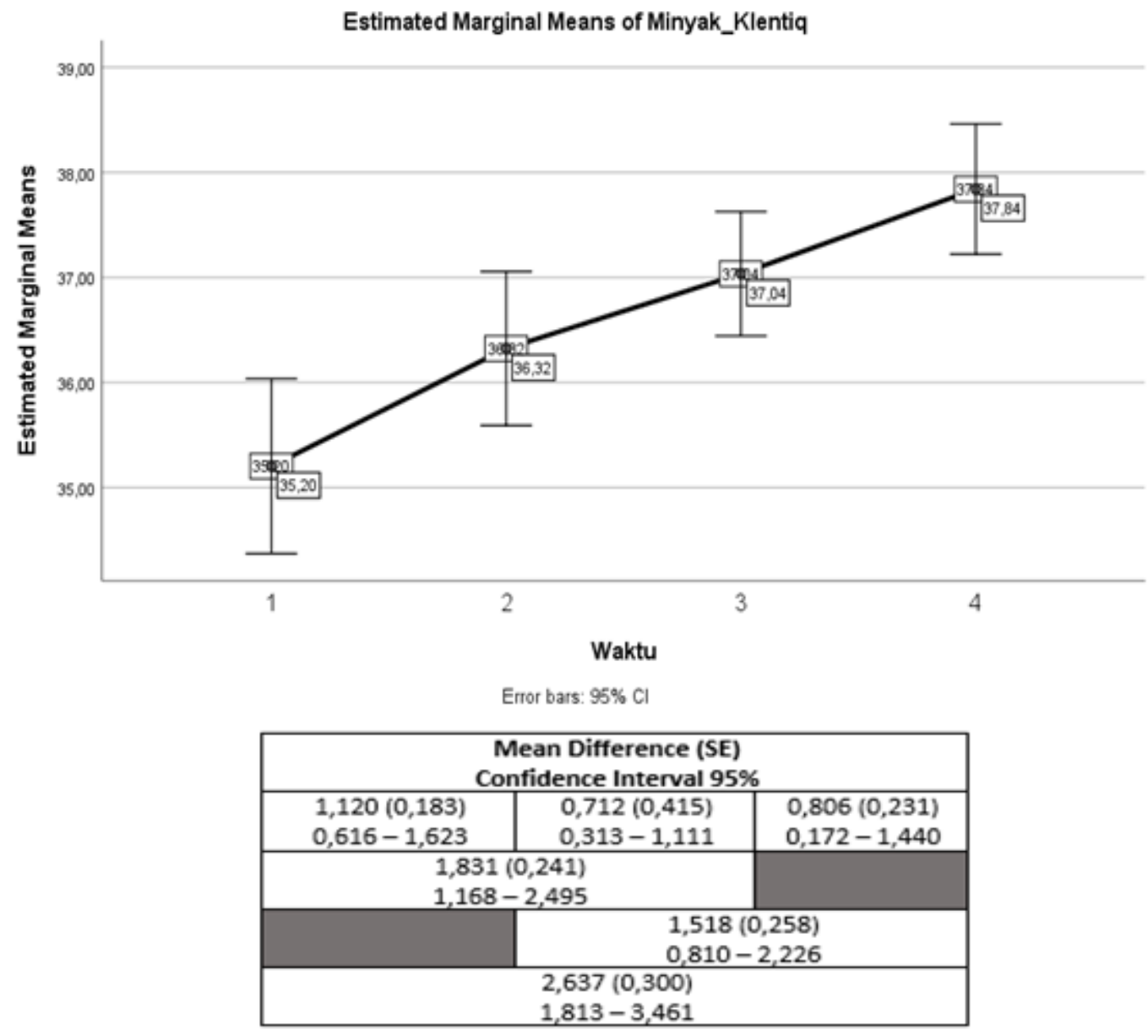

Gambar 1. Grafik perbandingan Kadar Hidrasi Kulit Lengan Kanan dengan Intervensi Minyak Klentiq pada Minggu ke-0 hingga Minggu ke -3 
Penggunaan pelembab secara rutin dapat menghambat Trans Epidermal Water Loss (TEWL) melalui mekanisme oklusi. Hidrasi sel-sel yang berada di stratum korneum berasal dari lapisan dalam epidermis yang bergerak keatas. Pelembab oklusif bertugas untuk mencegah dehidrasi yang terjadi pada stratum korneum. Hilangnya lipid-lipid intraselular, contohnya kolesterol, seramid, dan asam lemak bebas yang membentuk bilayer akan menyebabkan fungsi sawar air menjadi rusak. Tahapan proses yang dilakukan pelembab meliputi: memperbaiki fungsi sawar kulit, meningkatkan kandungan air kulit, mengurangi angka Trans Epidermal Water Loss (TEWL), meningkatkan kemampuan sawar lipid untuk menambil, menahan, dan mendistribusikan kembali air. (Lynde, 2001)

Salah satu jenis pelembab yang dapat digunakan adalah minyak kelapa dan minyak zaitun. Minyak kelapa atau Virgin Coconut Oil (VCO) yang diekstraksi langsung dari santan dengan proses basah di bawah kontrol kondisi suhu. Proses ekstraksi ini terutama untuk menghindari hilangnya komponen minor seperti pro-vitamin A, vitamin E dan polifenol karena iradiasi UV dari sinar matahari selama pengeringan kopra. VCO memiliki kandungan kaya akan asam lemak rantai sedang (MCFA), terutama asam laurat: yang lain termasuk asam kaproat, asam kaprilat dan asam kaprat. Sebuah studi yang dilakukan oleh Mansor et al., pada VCO yang diekstraksi melaporkan bahwa asam laurat isi berkisar antara 46,36\% hingga 48,42\% dan total MCFA dalam minyak (asam kaproat, kaprilat asam, asam kaprat dan asam laurat) berkisar antara 59,02\% hingga $62,27 \%$ dari total asam lemak. Menurut temuannya, kandungan asam laurat tertinggi dilaporkan dari sampel yang diekstraksi menggunakan proses fermentasi, diikuti oleh proses kering-segar, pendinginan, dan metode enzim. Nilai saponifikasi, karakteristik kimia penting lainnya, diukur rata-rata berat molekul dari semua asam lemak yang ada dalam VCO. Semakin tinggi nilai saponifikasi, semakin pendek asam lemak pada gliserol, menunjukan bahwa VCO mengandung jumlah asam lemak rantai pendek yang lebih tinggi. Mansor et al,. melaporkan saponifikasi nilai dari empat metode ekstraksi yang berbeda VCO juga dapat ditandai dengan adanya antioksidan. Tokoferol, antioksidan lipofilik alami, diketahui dapat ditemukan dalam minyak nabati termasuk VCO. Mansor et al,. mendeteksi tiga jenis tokoferol yang ada dalam VCO termasuk beta, gamma dan delta. Beta-tokoferol berkisar antara 0,04-0,05 mg/kg, gammatokoferol dari $0,01-0,05 \mathrm{mg} / \mathrm{kg}$, dan delta-tokoferol terdeteksi pada tingkat konsentrasi yang sangat rendah (1,30 x 10-5 hingga 1,10 x 10-3 mg/kg) dalam VCO. Kadar air adalah karakteristik kualitas penting lainnya untuk minyak dan lemak. Semakin rendah tingkat kelembaban akan meningkatkan umur penyimpanan dengan mencegah proses oksidasi dan ketengikan, sedangkan kadar air yang tinggi akan membantu hidrolisis. Mansor et al,. melaporkan konten kelembaban (\% wt) dan viskositas untuk VCO diekstraksi menggunakan empat metode ekstraksi. Viskositas tertinggi yang tercatat adalah dari metode kering-segar sedangkan yang terendah dari metode fermentasi (Dumancas et al., 2016; Shankar, Ahuja, \& Tracchio, 2013; Shijna Kappally, 2015; Yeap et al., 2015)

Minyak zaitun adalah minyak yang diekstrak dari buah pohon zaitun (Olea europaea). Ada beberapa metode untuk menghasilkan minyak zaitun, dengan cara proses mekanis tanpa menggunakan panas berlebih memberikan minyak zaitun berkualitas tinggi yang diklasifikasikan sebagai minyak zaitun murni (Virgin Olive Oil). Minyak zaitun telah banyak digunakan pada produk kosmetik, seperti formulasi perawatan kulit dan rambut. (Badiu, Luque, \& Rajendram, 2010; Chaiyana, Leelapornpisid, Phongpradist, \& Kiattisin, 2016; Shu, Zou, \& Yang, 2014) Ekstrak minyak zaitun murni mengandung 98\% hingga 99\% trigliserida dan 1\% hingga 2\% komponen minor. Didalam trigliserida, asam lemak utama diwakili oleh asam lemak tak jenuh tunggal (oleat), dengan sedikit asam lemak jenuh (palmitic, stearic) dan adanya asam lemak 
jenuh rantai panjang (linoleat dan $\alpha$-linolenat) disertai komponen minornya berupa $\alpha$-tokoferol, senyawa fenol, karotenoid ( $\beta$-karoten dan lutein), squalene dan fitosterol, yang semuanya memiliki sifat efek melindungi kulit. Antioksidan yang terkandung dalam minyak zaitun dapat mencari radikal bebas dan memberikan perlindungan dari peroksidasi. Senyawa yang penting dalam buah zaitun termasuk asam fenolik, fenolik alkohol, flavonoid, dan secoiridoid dengan alkohol fenolik zaitun berupa hydroxytyrosol dan tirosol. (Badiu et al., 2010; Slim Smaoui, 2012). Penelitian dari Harman menjelaskan bahwa setelah 30 menit paparan UV, tingkat $\alpha$ tokoferol di kulit berkurang sebesar 50\% hingga 60\%. Aplikasi topikal $\alpha$-tokoferol dengan jelas mengurangi kerusakan kulit. Harus diingat bahwa sinar UV memberikan efek negatif pada semua antioksidan, terutama pada karoten, dikarenakan menurunkan konsentrasi karoten baik di tingkat kulit maupun di plasma. Asupan karotenoid yang cukup (dengan sayuran dan juga dengan ekstrak minyak zaitun murni, yang mengandung $\beta$-karoten dan lutein) dapat direkomendasikan sebagai hal yang penting faktor pelindung kulit. Lutein memiliki efek langsung sebagai antioksidan dan bekerja secara sinergis dengan karotenoid, likopen, zat yang sangat aktif melawan photoaging kulit dan risiko kanker, tidak hanya pada kulit, tetapi juga jaringan lainnya. Komponen fenol yang terdapat di minyak zaitun memiliki antioksidan yang bekerja langsung pada kulit, terutama oleuropeine, yang bertugas sebagai radikal bebas yang baik di kulit. Khusus untuk senyawa squalene, yang terkonsentrasi fraksi non saponifikasi yang terdapat didalam minyak zaitun murni, membuatnya mirip dengan komposisi sebum. Squalene ditemukan dalam jumlah tinggi di sebum ( $\sim 12 \%$ dari komposisinya) dan bertindak sebagai agen kimia yang berguna untuk pembersihan radikal bebas, menghambat lipoperoksidasi yang diinduksi oleh UVA. Saat diminum, minyak zaitun telah dikonsumsi terbukti memberi perlindungan terhadap kulit. (Cicerale, Lucas, \& Keast, 2012; Franco et al., 2014; Viola \& Viola, 2009)

Penelusuran literatur juga memberikan penjelasan yang sesuai atau sejalan dengan hasil penelitian ini yaitu jurnal dari Shijna Kappally, Arun Shirwaikar, Sannie Shirwaikar dengan judul penelitian Coconut Oil - A Review of Potential Application, memaparkan bahwa minyak Cocos nucifera (minyak kelapa) telah dilaporkan sebagai agen penyembuhan luka yang efektif. Dalam studinya Nevin et al,. mempelajari efek topikal dari minyak kelapa murni pada komponen kulit dan status antioksidan selama penyembuhan luka di kulit pada percobaan tikus muda. Dalam studi mereka, hewan dirawat selama 10 hari dengan VCO, setelah 24 jam dengan adanya luka. Aktivitas penyembuhan VCO dievaluasi dengan memantau waktu untuk epitelisasi dan juga parameter jaringan granulasi luka seperti kelarutan kolagen, aktivitas glikohidrolase dan histopatologi jaringan granulasi. Hewan yang dirawat dengan VCO menunjukkan aktivitas penyembuhan luka yang jauh lebih cepat, ditunjukkan oleh penurunan waktu epitelisasi dan berbagai komponen kulit tingkat tinggi. Peningkatan signifikan aktivitas kolagen yang larut dalam pepsin dan aktivitas glikohidrolase yang diamati menunjukkan keterkaitan kolagen yang lebih tinggi dan pergantiannya. Mereka menyimpulkan bahwa aktivitas penyembuhan luka dengan menggunakan VCO merupakan efek kumulatif dari berbagai komponen aktif biologis minor yang ada. Jurnal dari Shijna Kappally, Arun Shirwaikar, Sannie Shirwaikar dengan judul penelitian Coconut Oil - A Review of Potential Application, juga menjelaskan bahwa studi yang dilakukan oleh Evangelista et al,. menyelidiki efek topikal VCO pada indeks SCORAD, Trans Epidermal Water Loss (TEWL) dan kapasitansi kulit pada dermatitis atopik ringan sampai sedang pada pasien pediatrik dengan menggunakan desain uji coba terkontrol secara acak. Sebanyak 117 pasien yang dimasukkan dievaluasi pada awal, dan kemudian pada minggu 2, 4, dan 8 dan hasilnya menyimpulkan keunggulan VCO dibandingkan minyak lainnya di antara pasien anak dengan AD ringan sampai sedang. (Kappally et al., 2015) 
Penelitian ini merupakan penelitian baru di Indonesia dikarenakan belum ada yang meneliti mengenai efektivitas Minyak Klentiq yaitu gabungan minyak kelapa dan minyak zaitun terhadap peningkatan kadar hidrasi kulit terutama pada kelompok lansia.

\section{KESIMPULAN}

Berdasarkan hasil penelitian yang telah dilaksanakan, maka dapat ditarik kesimpulan berupa hasil kenaikan hidrasi yang bermakna ( $p$-value $<0,001)$ antar pengukuran setelah pemberian intervensi berupa Minyak Klentiq selama 21 hari. Peningkatan kadar hidrasi paling tinggi adalah antara pengukuran minggu ke nol dengan minggu ke tiga yaitu sebesar 2,637 (0,300)\%.

\section{Ucapan Terima Kasih}

Ucapan terimakasih diberikan kepada Kepala Panti STW Ria Pembangunan Cibubur yang telah memberikan sarana dan prasarana untuk menjadi tempat penelitian selama 21 hari serta kepada PT. Sukma Skin Treatment (PT. SST) yang telah memberikan hibah dana penelitian untuk terselenggaranya penelitian ini

\section{REFERENSI}

Badiu, D., Luque, R., \& Rajendram, R. (2010). Effect of Olive Oil on the Skin. In Olives and Olive Oil in Health and Disease Prevention. https://doi.org/10.1016/B978-0-12-3744203.00123-6

Cao, C., Wan, S., Jiang, Q., Amaral, A., Lu, S., Hu, G., ... Wan, Y. (2008). All-trans retinoic acid attenuates ultraviolet radiation-induced down-regulation of aquaporin-3 and water permeability in human keratinocytes. Journal of Cellular Physiology. https://doi.org/10.1002/jcp.21336

Chaiyana, W., Leelapornpisid, P., Phongpradist, R., \& Kiattisin, K. (2016). Enhancement of antioxidant and skin moisturizing effects of olive oil by incorporation into microemulsions. Nanomaterials and Nanotechnology. https://doi.org/10.1177/1847980416669488

Cicerale, S., Lucas, L. J., \& Keast, R. S. J. (2012). Antimicrobial, antioxidant and antiinflammatory phenolic activities in extra virgin olive oil. Current Opinion in Biotechnology. https://doi.org/10.1016/j.copbio.2011.09.006

Dumancas, G. G., Kasi Viswanath, L. C., de Leon, A. R., Ramasahayam, S., Maples, R., Koralege, R. H., ... Castles, S. (2016). Health benefits of virgin coconut oil. In Vegetable Oil: Properties, Uses and Benefits.

Fitzpatrick, T. B., Wolff, K., Goldsmith, L. A., Katz, S. I., Gilchrest, B. A., Paller, A. S., ... Zouboulis, C. C. (2008). Fitzpatrick's dermatology in general medicine [electronic resource]. In McGrawHills AccessMedicine Clinical library.

Franco, M. N., Galeano-Díaz, T., López, Ó., Fernández-Bolaños, J. G., Sánchez, J., De Miguel, C., ... Martín-Vertedor, D. (2014). Phenolic compounds and antioxidant capacity of virgin olive oil. Food Chemistry. https://doi.org/10.1016/j.foodchem.2014.04.091

Hurlow, J., \& Bliss, D. Z. (2011). Dry Skin in Older Adults. Geriatric Nursing. https://doi.org/10.1016/j.gerinurse.2011.03.003

Kappally, S., Shirwaikar, A., \& Shirwaikar, A. (2015). Coconut oil - A review of potencial applications. Journal for Drugs and Medicines. https://doi.org/10.15254/H.J.D.Med.7.2015.149

Leslie, T. A. (2016). Itch Management in the Elderly. Current Problems in Dermatology (Switzerland). https://doi.org/10.1159/000446094 
Lynde, C. W. (2001). Moisturizers: what they are and how they work. Skin Therapy Letter. Population Reference Bureau. (2016). 2016 World Population Data Sheet. 2015 World Population Data Sheet. https://doi.org/10.2307/1972177

Robinson, M., Visscher, M., Laruffa, A., \& Wickett, R. (2010). Natural moisturizing factors (NMF) in the stratum corneum (SC). I. Effects of lipid extraction and soaking. Journal of Cosmetic Science. https://doi.org/10.1111/j.1468-2494.2010.00591_2.x

Seyfarth, F., Schliemann, S., Antonov, D., \& Elsner, P. (2011). Dry skin, barrier function, and irritant contact dermatitis in the elderly. Clinics in Dermatology. https://doi.org/10.1016/j.clindermatol.2010.07.004

Shai, A., Maibach, H., \& Baran, R. (2009). Handbook of Cosmetic Skin Care (2nd Edition). In Handbook of Cosmetic Skin Care (2nd Edition). https://doi.org/10.3109/9781616310004

Shankar, P., Ahuja, S., \& Tracchio, A. (2013). Coconut oil: A review. Agro Food Industry HiTech.

Shijna Kappally, A. S. and A. S. (2015). Coconut Oil- A Review of Potential Applications. Hygeia.J.D.Med. https://doi.org/10.15254/H.J.D.Med.7.2015.149

Shu, Z., Zou, S., \& Yang, H. (2014). Preparation of anti-aging collagen face mask. Journal of Chemical and Pharmaceutical Research.

Slim Smaoui. (2012). Cosmetic emulsion from virgin olive oil: Formulation and bio-physical evaluation. AFRICAN JOURNAL OF BIOTECHNOLOGY. https://doi.org/10.5897/ajb12.163

The World Bank. (2012). Population ages 65 and above (\% of total ). The World Bank Website.

Viola, P., \& Viola, M. (2009). Virgin olive oil as a fundamental nutritional component and skin protector. Clinics in Dermatology. https://doi.org/10.1016/j.clindermatol.2008.01.008

White-Chu, E. F., \& Reddy, M. (2011). Dry skin in the elderly: Complexities of a common problem. Clinics in Dermatology. https://doi.org/10.1016/j.clindermatol.2010.07.005

Yeap, S. K., Beh, B. K., Ali, N. M., Yusof, H. M., Ho, W. Y., Koh, S. P., ... Long, K. (2015). Antistress and antioxidant effects of virgin coconut oil in vivo. Experimental and Therapeutic Medicine. https://doi.org/10.3892/etm.2014.2045 